\title{
DISTRIBUTION OF COBALT, MANGANESE AND IRON IN THE SKIN AND HAIR OF WEST AFRICAN DWARF SHEEP AND GOATS IN NIGERIA: THE
}

\author{
ONWUKA, S.K ${ }^{1^{*}}$, AVWIORO, O.G. ${ }^{1}$ AKPAN, M.0 ${ }^{1}$. AND YAHAYA AHMED ${ }^{2}$ \\ ${ }^{1}$ Department of Veterinary Anatomy, University of Ibadan, Ibadan. \\ ${ }^{2}$ Department of Veterinary Anatomy, University of Maiduguri, Maiduguri.
}

The distribution of cobalt (Co), manganese ( $\mathrm{Mn}$ ) and iron ( $\mathrm{Fe}$ ) was investigated in the skin and hair of 16 West African Dwarf sheep and goats. All three trace elements were present in varying amounts in both tissues. There were, however, some regional intraand interspecies differences Some of these differences were found to be statistically significant. These findings are discussed with reference to their possible implications for cutaneous manifestation of deficiency and other disease syndromes in the animals.

Keywords: Cobalt, Manganese, Iron, Sheep, Goat, Skin, Hair.

${ }^{*}$ Author for correspondence

\section{INTRODUCTION}

The rationale for embarking on this series of studies has been adumbrated previously (Onwuka et al 2000). It includes, inter alia, the need to provide basic information for a database on the trace element endowments in the hair and skin of domestic animals, but particularly, small ruminants in Nigeria. There is also the need to provide additional diagnostic tools for differential diagnosis of the ever-changing disease profiles of these animals in the humid tropical sub-region.

The importance of small ruminants in the domestic economy of the rural populace in Nigeria cannot be overemphasized (Wilson, 1982; ILCA 1985). In addition to being additional sources of farm income and buffering farmers in times of crop failure, they oftentimes are also regarded as some kind of status symbols.

There is an increasing tendency in livestock farming in the tropics towards intensive and semi-intensive production system (Devendra and McLeroy, 1982). Greater consideration is now been given to the health and nutritional needs of livestock. It has frequently been the experience in our ambulatory veterinary service to rural communities that one finds sheep, goats and other domestic animals with various health problems brought to the ambulatory van. It so very often transpires that some of these problems can be ameliorated by adequate nutrition while some do, indeed, need medication. It is in the light of such findings that the current study was initiated. It was designed in such a way that the outcome would be useful to both the owners of the animals and the health care providers the veterinarians, nutritionists, basic and applied scientists and even the govenunent policy makers.

\section{MATERIALS AND METHODS}

The methods described previously by Onwuka et al (2000) for the determination of trace elements in the skin and hair were modified slightly for the purpose of this study. The drawbacks of those procedures included (a) the erratic supply of electricity (b) the unreliability of the temperature-measuring device of the furnace and (c) the possibility of loss of material as a result of (a) and (b) above. Thus, instead of incinerating the samples in a furnace as previously described. they were digested with a mixture of nitric acid and perchloric acid in the ratio of $1: 3$. The skin and hair samples were obtained from 8 sheep and 8 goats of the dwarf breed variety slaughtered at the small ruminant section of Bodija abattoir, Ibadan. The samples were obtained from (1) the neck region (2) the shoulder region (3) the mid flank (4) the ventral abdomen (5) the croup (6) the lateral thigh region. We actually had to pay for the skins to be flayed instead of dehaired by burning, as is the butchers' practice. The samples were treated as previously described, care being taken to reduce extraneous contamination to the barest minimum. $0.5 \mathrm{~g}$ of each of the dried skin and hair from each sample site was put in individual bijoux bottles containing $4.5 \mathrm{ml}$ of a 1:3 mixture of nitric acid and perchloric acid. The bottles were then put in a microwave oven at $450 \mathrm{C}$ for 5 minutes to digest. They were brought out and allowed to cool on the bench. $45 \mathrm{ml}$ of ultra pure water obtained by double distillation (or de-ionised water) were added to each bottle. The mixture was then thoroughly agitated and allowed to settle. $10 \mathrm{ml}$ of the supernatant were decanted from each bottle for elemental analysis with an atomic absorption spectrophotometer (AAS).

\section{RESULTS}

The data obtained for each element in the skin and hair of each species are displayed on Tables I and 2 and shown graphically in figures 1, 2,3. for cobalt, manganese and iron respectively. The data were further subjected to statistical analysis using the single factor or univariate analysis of variance (ANOVA) technique in a computer. The following pattern was discernible.

\section{A. Skin (Table 1) \\ 1. Cobalt}

There was more cobalt (mean $19.35 \pm 7.75 \mathrm{mg} / 1$ ) in the skin of sheep than in the skin of goats (mean $15.35+1.35 \mathrm{mg} / \mathrm{l}$. This difference was however not statistically significant $(p=0.782558)$. The highest amount of cobalt (34.3ng/1) was found in the shoulder region of sheep whilst this distinction (I $6.9 \mathrm{mg} / \mathrm{c}$ ) belonged to the abdominal region in the goat. The 
lowest quantity of cobalt in the skin of the sheep $(9.7 \mathrm{mg} / 1)$ was in the thigh region while that in the goat $(I$ $2.9 \mathrm{mg} / 1$ ) was in the shoulder region. While the regional differences in the sheep were statistically significant those in the goats were not.

\section{Manganese}

The skin of the sheep contained significantly more manganese $(8.48+2.95 \mathrm{mg} / 1)$ than the skin of goats (4.97 $\pm 2.95 ; \quad p=0.021619)$. Infact there was more manganese in almost every region of sheep skin than in the corresponding area of goatskin. In sheep the highest amount of manganese $(12.72 \mathrm{mg} / 1)$ was found in the shoulder region while the lowest quantity $(3.43 \mathrm{mg} / 1)$ was found in the thigh region. In the goat the corresponding values and regions were $5.41 \mathrm{mg} / \mathrm{l}$ (neck) and 4.52mg/l (shoulder).

\section{Iron}

Iron was the most abundant of the three elements investigated. Again the skin of sheep contained more iron $(47.27 \pm 18.98 \mathrm{mg} / 1)$ than that of goats $(36.47 \pm$ $2.84 \mathrm{mg} / 1)$. The difference in these mean values were however not statistically significant $(p=0.238857)$. The highest concentration of iron in the skin of the sheep was in the neck region $(78.4 \mathrm{mg} / 1)$ while the lowest $(28.3 \mathrm{mg} / 1)$ was in the mid-side (flank) region. In the goat skin the highest value $(41.1 \mathrm{mg} / 1)$ was in the thigh area while the lowest $(33.5 \mathrm{mg} / 1)$ was in the shoulder area.

\section{B. Hair}

1. Cobalt (Table 2): The hair of sheep had more. cobalt $($ I 2.2,1.69mg/1) than that of goats (mean 10. 76 \pm 1. $(7 \mathrm{mg} / 1)$. This difference was not significant statistically $(p=0.28322)$. The neck region of the sheep had the most cobalt $(14.91 \mathrm{mgl})$ in the hair while the abdomen had the least $(9.1 \mathrm{mg} / 1)$. In goats the hair from the shoulder region contained the most cobalt (I $2.9 \mathrm{mg} / 1)$. while that from the croup area contained the least $(8.7 \mathrm{mg} / 1)$. The mean cobalt content of goat skin $(15.35+1.39 \mathrm{mg} / 1)$ was statistically significantly different from the mean cobalt content of goat hair (IO. $76+1.67 \mathrm{mgl}(p=0.000831)$. However, although sheep skin had more cobalt(19.35+7.75mg/l) than sheep hair $(12.2+1.69 \mathrm{mg} / 1)$ this difference was not significant $(p=0.071689)$.

2. Manganese (Table 2): There was significantly less manganese $(6.03+1.21 \mathrm{mg} / 1)$ in sheep hair than in goat hair $(21.2+407 \mathrm{mg} /(p=0.00188)$ In each region of the body goats had more manganese in the hair than the sheep. The highest amount of manganese in sheep hair $(7.41 \mathrm{mg} / 1)$ was found in both the shoulder and abdominal areas while the least quantity $(4.46 \mathrm{mg} / 1)$ was from the mid-side or flanks region. In the goat the shoulder region had the most manganese in the hair (34.1 I mg/1) while the flank region had the least (I $8.52 \mathrm{mg} / 1)$. In both species the regional difference were not significant. Sheep skin contained more manganese $(8.48+2.87 \mathrm{mg} / 1)$ than sheep hair $(6.03+1.21 \mathrm{mg} / 1)$. This difference was not significant $(p=0.054428)$. And although goat hair had a lot more manganese $(21.2+4.07 \mathrm{mg})$ than goat skin $(4.97+2.97 \mathrm{mg} / 1)$ analysis showed that the difference was not significant at the 95\% level $(P=0.069966)$.

3. Iron (Table 2): Unlike the situation in the skin (Table 1) there was more iron in goat hair $(64.82+30 \mathrm{mg} / 1)$ than in sheep hair $(58.68+5.7 \mathrm{mg} / 1)$. This difference as in the skin was not statistically significant $(p=0.33843)$. The thigh region in the sheep had the most iron $(61.6 \mathrm{mg} / 1)$ while the shoulder region had the least $(45.7 \mathrm{mg} / 1)$ In goats hair from the flank had the highest level of iron $(130.3 \mathrm{mg} / \mathrm{L})$ while the croup hair had the least $(50.0 \mathrm{mg} / \mathrm{L})$. In both species the differences in body region were not significant. Sheep hair had more iron $(58.68+5.7 \mathrm{mg} / 1)$ than sheep skin but the difference was not significant $(p=0.9146)$. Similarly, goat hair had more iron $(64.82+30.9 \mathrm{mg} / 1)$ than goat skin but the difference was not significant $(p=0.3231)$.

Table 1:

Cobalt, Manganese and Iron content of sheep and Goat skin

\begin{tabular}{|lllllll|}
\hline & Co $(\mathbf{m g} / \mathbf{l})$ & \multicolumn{2}{l}{ Mn (mg/l) } & \multicolumn{2}{l|}{ Fe (mg/l) } \\
\hline & Sheep & Goat & Sheep & Goat & Sheep & Goat \\
\hline Neck & 22.1 & 16.3 & 9.21 & 5.41 & 63.4 & 38.9 \\
\hline Shoulder & 34.3 & 12.9 & 12.72 & 4.52 & 76.4 & 33.5 \\
\hline Flank & 15 & 15.9 & 7.3 & 4.74 & 28.3 & 34.1 \\
\hline Abdomen & 19.8 & 16.9 & 10.4 & 5.23 & 29.3 & 37.2 \\
\hline Croup & 15.2 & 16 & 7.81 & 5 & 52 & 34 \\
\hline Thigh & 9.7 & 14.1 & 3.43 & 4.9 & 32.2 & 41.1 \\
\hline Total & 116.1 & 92.1 & 50.87 & 29.8 & 283.6 & 218.8 \\
\hline Mean & 19.35 & 15.35 & 8.48 & 4.95 & 47.27 & 36.47 \\
\hline SDev & 7.75 & 1.39 & 2.87 & 2.95 & 18.98 & 2.84 \\
\hline
\end{tabular}

Table 2:

Cobalt, Manganese and Iron content of sheep and Goat hair

\begin{tabular}{|lllllll|}
\hline & \multicolumn{2}{l}{ Co $(\mathrm{mg} / \mathrm{l})$} & \multicolumn{2}{l}{ Mn (mg/l) } & \multicolumn{2}{l|}{ Fe (mg/l) } \\
\hline & Sheep & Goat & Sheep & Goat & Sheep & Goat \\
\hline Neck & 14.9 & 12.8 & 6.1 & 21.8 & 48.2 & 52.6 \\
\hline Shoulder & 12.3 & 12.9 & 7.4 & 34.1 & 45.7 & 68.2 \\
\hline Flank & 12.3 & 8.8 & 4.5 & 18.5 & 54.6 & 130.3 \\
\hline Abdomen & 9.1 & 10.7 & 7.4 & 22.6 & 48.1 & 53.6 \\
\hline Croup & 12.7 & 8.7 & 4.5 & 20.2 & 45.9 & 34.2 \\
\hline Thigh & 11.9 & 10.7 & 6.29 & 25.0 & 61.6 & 50.0 \\
\hline Total & 73.2 & 64.6 & 36.2 & 139.2 & 304.1 & 388.9 \\
\hline Mean & 12.2 & 10.8 & 6.0 & 21.2 & 58.7 & 64.8 \\
\hline SDev & 1.7 & 1.7 & 1.21 & 4.1 & 5.7 & 30.9 \\
\hline
\end{tabular}




\section{DISCUSSION}

This study has revealed that the elements cobalt, manganese and iron are present in the skin and hairs of West African dwarf sheep and goats. On a comparative basis iron was the most abundant of the three elements while manganese was the least. Each species had its own peculiar distribution pattern for each of the elements between the hair and the skin and amongst the various body regions. These species, tissue and regional differences may not be surprising given the varied roles played by the elements and the organs themselves in the normal structure and function of the animals. For instance, various regions of the skin and coat of the animal, even though similar in gross structure, come under different influences in the course of its daily a Other factors that are known to influence the distribution of trace elements in the tissues and organs of man and animals include the diet, soil and vegetation types (Underwood, 1970; Suttle, 1975; Keen and Graham, 1989)

Elemental cobalt provides about $4.5 \%$ of the molecular weight of vitamin $\mathrm{B}_{12}$ (Cobalamin) (Hays and Swenson, 1970). Vitamin $B_{12}$ is a complex vitamin whose deficiency could precipitate pernicious anaemia in man Ruminant animals escape this predicament because their ruminal micro-flora can synthesize vitamin $B_{12}$ in Vivo unless there is a shortage of dietary cobalt. We are of the opinion that the cobalt that was found in the skin and hair in this study was not an external contamination but of a haematogenous origin through the diet. There was more cobalt in sheep than in goats and for both species the forequarters had more cobalt than the hindquarters. The reason for these disparities is unknown but a similar observation had been reported in the distribution of zinc in sheep and goats. (Onwuka and Avwioro, 2000).

Manganese functions both in enzyme activation and as part of metalloenzyme in manganese-activated reactions (Bach and Whitehouse, 1954; Keen and Graham, 1989) Manganese is also important in glycoprotein synthesis and particularly chondroitin sulphate. Deficiency of manganese has been known to cause abnormalities in cartilage development. (Smith and Gawthorne, 1975; Harris et. al., 1999).

In this study the sheep had more manganese in the skin than the goats but the reverse was the case in the hair. Intra-species, sheep had more manganese in the skin than the hair but the opposite was the case with the goats. We do not for certain the reason for these differences some of which are statistically significant, but we do suggest that they indicate a degree of microstructural differences between these species. Could these differences include the micro-vasculature, as manganese has been associated with the membranes of erythrocytes and mitochondria (Banks, 1979; Esievo et. al., 1986)?

Iron was the most abundant of the three metals assayed. This is not surprising given the abundance of element in the soil, plant and animal tissues (Suttle, 1975). Iron is essential for the synthesis of haemoglobin, myoglobin and the cytochromes (Smith, 1989; Harris et. al., 1999). These authors further advanced the argument that good quality natural diet should contain enough iron to meet the requirements of even fast growing animals. Iron deficiency is not to be a limiting factor to animal production in the tropics rather there could a risk of toxicity (nutritional siderosis) where excessive supplementation occurs (Anosa and Kaneko, 1983; Hays and Swenson, 1990; Harris et. al., 1999)

In this study the sheep had more iron in the skin than did the goats. We cannot adduce any reason for this from this study except to speculate that the boisterous habits of the goat,predispose the skin and its adnexa to a more rapid turnover in circulatory matters than is probably the case with the sheep. Sluggish flow through the skin of sheep would trap more blood in the organ at any one time. As iron is more associated with haemoglobin in the erythrocytes this would be so reflected in any assay. This thesis has, however, to be tested experimentally.

In conclusion, the skin and hair of the dwarf breeds of small ruminants in Nigeria contain varying amounts of cobalt, manganese and iron. Although their mode of occurrence is not known from this study their probable function would be stabilizing the integrity of the cells and the tissues and organs they compose.

\section{Acknowledgement}

We gratefully acknowledge a 1996 University of Ibadan Senate Research grant to the first author, which was used to part finance this study.

\section{REFERENCES}

Anosa, V. O. and Kanckb, J.J. (1983) Pathogenesis of $\mathrm{T}$ brucei infection in deer mice (Peromyscus maniculatus) Haematologic, erythrocytic, Biochemical and iron metabolic aspects Am. J. Vet. Res. 44: 639644.

Bach, S. J. and Whitehouse,D. B.(1954) Purification and properties of arginase Biochem J. 57: 31-36

Banks, K. L. (1979) In vitro binding of Trypanosoma congolense to erythrocytes. J. Protozoology 26: 103108.

Devendra, C. and McLeroy, G.B. (1982) Goat and Sheep Production In the Tropics. Longmans, London.

Esievo, K.A.N.; Saror, D.I.; Kolo, M.N and Eduvie, 1. 0. (1986). Erythrocyte surface sialic acid in Ndama and Zebu cattle .J. Comp. Path. 96:95-99

Harris, P.A., Frape, D.L., Jeffcott, L.B., Lucas D, Meyer. H and Savage, C.J. (1999) Equine Nutrition and metabolic Disease. In: The Equine manual Ed AJ Higgins and Wright. W.B. Saunders Limited, London. Philadelphia Sydney, Tokyo, Toronto. Pp 123-186.

Hays, V. W. and Swenson, M.J. (1970) Minerals In: Dukes Physiology of Domestic Animals M. J. Swenson (ed.) 8th edition. Cornell University Press Ithaca and London.

International Centre for Livestock in Africa ILCA (1985) Sheep and Goats in Humid West Africa. ILCA Addis Ababa,

Ethiopia.

Keen, C. 1. and Graham, 1. W. (1989) Trace Elements In: Clinical Biochemistry of Domestic Animals. Kaneko, J.J. (ed.) 4" edition Academy Press pp.753-795.

Onwuka, S. K. and Avwioro, 0. G. (2000). 
Comparative Studies In the Distribution of Trace Elements in the Skin and Hair of West African Dwarf Sheep and Goats in Nigeria. Proceedings of the glh Scientific Congress of the Anatomical Society of West Africa (ASWA) 19t'-22 nd October 2000, University of Ibadan, Ibadan. p9

Onwuka, S. K., Avwioro, O.G. and Olaifa, A. K. (2000). Preliminary Observations on Trace Element Contents of the Skin andPelage of West African Dwarf (WAD) Goat. Afr. J. Biomed. Res. 3: 149-152

Smith, J. E. (1989) Iron metabolism and its disease. In: Clinical Biochemistry of Domestic Animals. J. J. Kaneko (ed.) 4th ed. Academic Press San Diego, California. 13 Smith, R. M. and Gawthorne, J. M. (1975) The biochemical basis of deficiency of zinc, manganese, copper and cobalt in animals In: Trace Elements in SoilPlant-Animal Systems. D.J.D. Nicholas and R.R. Egan eds. Academic Press New York.

Suttle, N. F. (1975) Trace Elements Interactions in Animals. In: and R.R. Egan (eds.) Acad. Press New York and London.Trace Elements in Soil-plant-Animal Systems. D.J.D. Nicholas

Underwood, E.J. (1971) Trace elements in human and animal nutrition 3rd edition Acad. Press New York and London.

Wilson, R.T. (1982) Husbandry, Nutrition and Productivity of Goats and Sheep in Tropical Africa. In: Small Ruminant Breed Productivity in Africa. Ed. Gatenby Ruth, M. and Trail, J.C.M. ILCA, Addis Ababa, Ethiopia.

Received: February 2001

Accepted in final form: July 2001 